Title: Wildlife management for rural development...

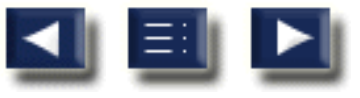

\section{Trees as savings and security for the rural poor}

\section{R. Chambers and M. Leach}

Robert Chambers, formerly at the Institute of Development Studies, Sussex, UK, is currently a visiting professor at the Administrative Staff College of India, Hyderabad. Melissa Leach is a postgraduate social anthropology student at the School of Oriental and African Studies, university of London This article is adapted with permission from a paper originally prepared for the Institute Of Development Studies, and subsequently published in World Development, Vol. 17, No. 3.

For savings and security, trees are comparable with jewellery, large stock, small stock, land and bank deposits. The disadvantages of trees may include insecure or unclear rights, restrictions on cutting and selling when needed, and problems with marketing; but common advantages include cheap and easy establishment, rapid appreciation in value, divisibility to meet needs closely, and regeneration after cutting. More empirical studies are needed on the use and potential of trees as poor people's savings banks. The policy implications of present evidence and analysis include tree reform, improved marketing and prices and, above all, vesting poor people with secure and full ownership of trees, with rights to harvest, cut and sell that are similar to the withdrawal rights of depositors in savings banks.

Trees have significant importance and potential as savings and security for the poor, and for use to meet contingencies. This potential can be understood in the light of the vulnerability of the rural poor to various contingencies, how this vulnerability has been neglected by professionals, and how it has been changing over time.

\section{trees have significant importance and potential as savings and security for the poor}

In normal professional usage, poverty is a synonym for deprivation. Reflecting the urban and industrial origins of poverty studies, poverty is defined in terms of low incomes or outlays. Definitions tend not to take account of stocks or assets.

Poverty defined in this way encompasses only one dimension of deprivation. Others include physical weakness, isolation, powerlessness and vulnerability. Of these, it is understandable that vulnerability is frequently overlooked. Professionals who define poverty are usually not themselves vulnerable. In contrast with the poor, they are cushioned in various ways against contingencies. If they live in rich countries, they have a safety net in social security, and in cases of sickness or accident, medical services are likely to be free or heavily subsidized. If they live in poor countries, they are probably relatively well off and have some means of meeting sudden or large needs. Not being vulnerable themselves, it is easy for the members of professional elites to underestimate the importance of vulnerability to contingencies to the poor. trace have significant importance and potential as savings and security for the poor.

Contingencies can take many forms. They may be sudden and unexpected; they may be slow 
in onset; or they may be large needs that can be foreseen. Five categories can be identified:

- social conventions, such as dowries, bride-wealth, weddings, funerals, and other ceremonial and social needs;

- disaster, such as theft of assets, loss by fire, death of animals, floods, droughts, epidemics of plant or animal diseases, civil disturbance and war, and food shortages and famines;

- physical incapacity, including disablement, sickness, the child-bearing sequence of pregnancy, childbirth and the postnatal period, old age, and accidents;

- unproductive expenditure, such as failures in small enterprises, litigation or gambling, and fees for schooling or apprenticeships that do not pay off; and

- exploitation, including excessive demands and illegitimate acts the powerful, such as exorbitant interest demands by money-lenders, expropriation of property, intimidation, and blackmail.

For a poor household, any of these can lead to further impoverishment, when assets have to be mortgaged or sold, or damaging obligations accepted. This often has a ratchet effect, being difficult or impossible to reverse. When a productive asset is thus lost, it is even harder to return to the previous position.

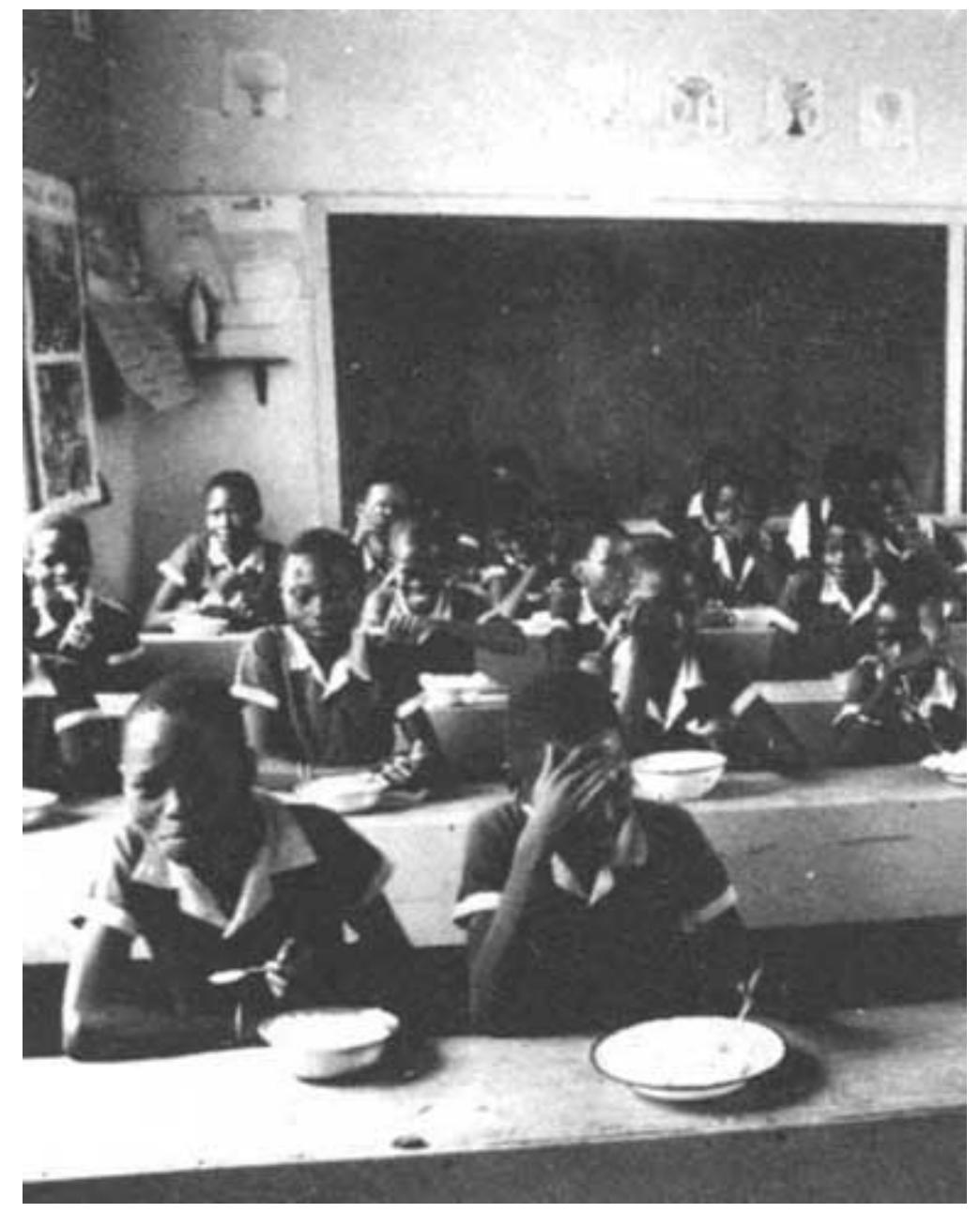




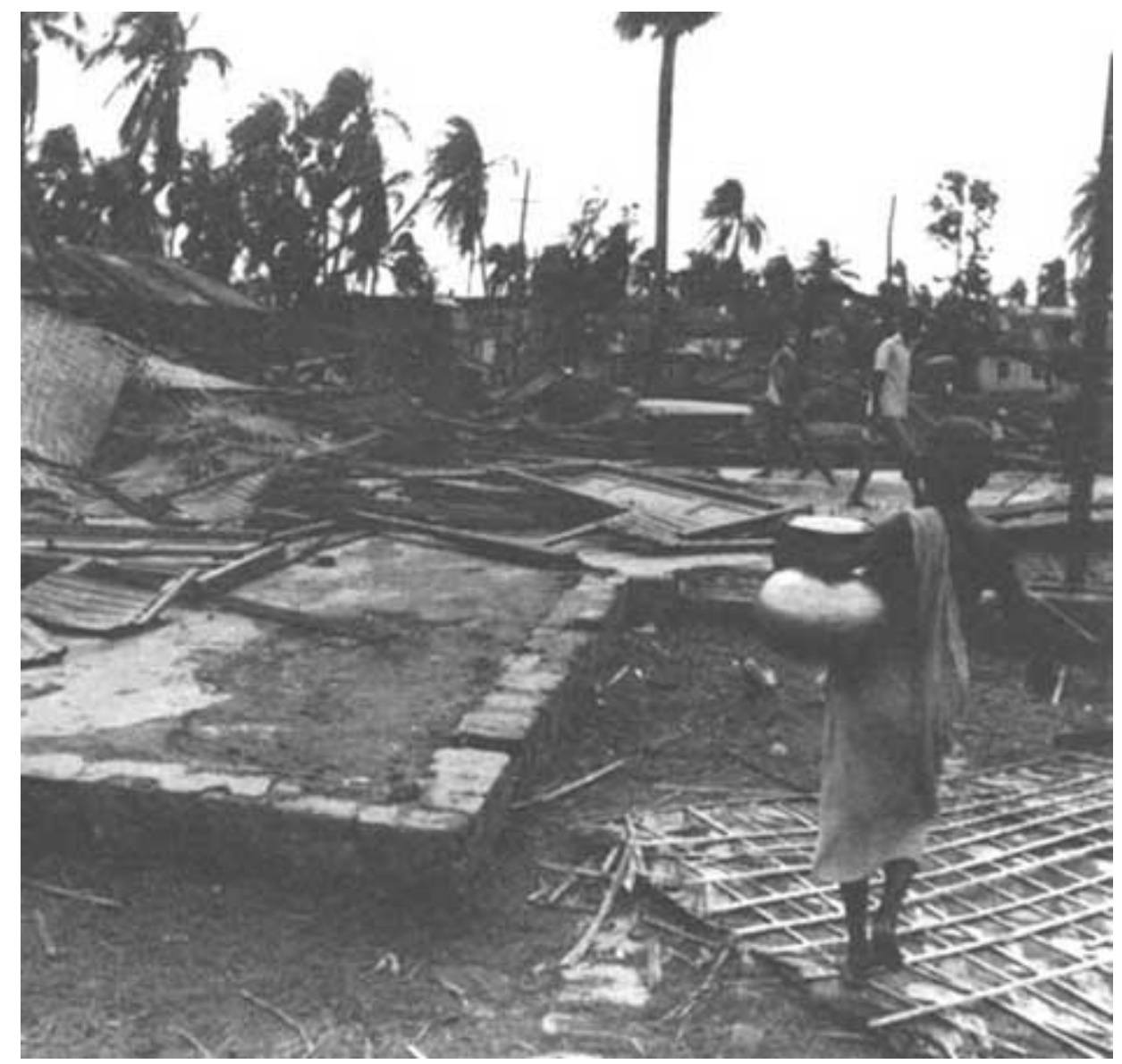

\section{The neglect of contingencies and assets}

Reducing vulnerability to contingencies is, however, rarely a direct objective of government rural development programmes. If such programmes are successful, they may reduce vulnerability through flows of food and income which meet consumption needs at bad times of the year, or which allow savings and investment. But few programmes. try to reduce vulnerability directly by enabling poor people to gain disposable assets that they can realize at will to meet contingencies. For example, India's large-scale Integrated Rural Development Programme (IRDP) provides poor people with economic assets, but these are intended to generate income that will raise them above the poverty line, not give them lump sums to meet contingencies. But the priorities of the poor are not necessarily those of the planners. In a survey in Gujarat, Hirway (1986, p. 140) found people not in the IRDP who wanted the scheme for its cheap subsidized asset, seeing it as a desirable acquisition because of good resale value. "The asset therefore can be used to meet any type of emergency like social functions (marriage, death, birth, etc.), illness in the family, or consumption needs."

This priority of the poor themselves car. be understood in terms of the changes that have been taking place in many agrarian societies. First, in many rural areas the costs of meeting contingencies have risen, as have dowry prices in India, and health treatment in much of subSaharan Africa and elsewhere. Second, mutual help through sharing and patron-client relations has been eroded or disappeared. Earlier, patrons often provided security by advancing loans to help their dependent clients meet large or sudden needs. With labour now more on an employer-employee cash basis and with weaker mutual obligations, poor people face a new defenselessness. Although some ethnographic studies have described contingencies and how they are met, such as Bailey's (1957)account of sales of land and jewellery in a village in Orissa; Parkin's (1972) study of sales of land and palm trees in Kilifi District, Kenya; and Cain's (1981) study of reasons for sale of land in three villages in India and one village in Bangladesh, as yet there has been to our knowledge no comparative 
analysis across cultures of types of contingencies and assets to indicate the relative value to poor people of different types of assets; or of how poor people use assets, and in what sequences, to deal with contingencies and to prevent or mitigate impoverishment.

A further oversight in this context has been trees. Some social anthropologists have considered farmland trees in detail, but more often in relation to cultural traditions surrounding them than to their place in a poor household's domestic economy (Srinivas, 1976, p.136; Malhotra and Basak, 1984).

\section{CONTINGENCIES include social conventions, disasters and physical incapacity}

A search of the available literature that can be broadly grouped under the term "community forestry," particularly that dealing with India, revealed a disappointing lack of information about how the trees planted under farm and community forestry projects were actually used. In part this reflected the relative newness of most schemes, but it also reflected a real gap in research. The prevailing view among most state governments and their sponsoring agencies was that planting trees was an end in itself; hence official project evaluation documents stressed seedling adoption rates and target areas of planting achieved (World Bank, 1983a, b). Few studies explored small farmers' motivations in undertaking farm and community forestry and none, to our knowledge, examined in detail how those trees that had been planted contributed to the domestic economy. Hence evidence of their actual or planned use as savings banks did not come to light. Some researchers, perhaps stimulated by the social forestry debate, described the traditional uses of spontaneously planted farmland trees (Brokensha, Riley and Castro, 1983; Campbell and Bhattrai, 1983; Poulsen, 1983). However, like the agroforestry literature, these studies emphasized flows (of fuel, fruit, fodder and other products) rather than the meeting of contingency crises. The few authors who mentioned the potential of trees as savings banks did so more in passing (Mascarenhas, 1983, p.57; Shah, 1984, p. 65; Murray, 1986) than as a central theme or focus.

These gaps in knowledge and analysis have many explanations. In general, trees in villages or on farmland have been ignored by professionals agricultural scientists have been concerned with crops, veterinarians and animal husbandry specialists with domestic animals, and foresters with trees in government forests and plantations, rather than on private land. Foresters and others have also been influenced by rich country and temperate climate experience, where slow tree growth limits the value of trees as assets (Douglas et al., 1982,p.195).For their part, social anthropologists tended until recently to concentrate much of their attention on people either in remote locations where trees and tree products were abundant and therefore had little value for meeting contingencies, or in pastoral areas where trees were not a good source of money. A further factor has been the time lag in recognizing the implications of the rapid rise in value of timber, fuelwood, charcoal and other tree products. Trees that had little capital value before the penetration of the market and the fuelwood shortages of the energy crisis have now increased substantially in worth, but policy has been slow to adjust to the change. Finally, tree tenure has recently been better recognized as a comparative subject (Fortmann and Riddell, 1985; Fortmann and Bruce, 1988), emphasizing that rights to trees are often separate from land tenure, and sparking new ideas about tree reform.

Thus, in many rural areas of the Third World, costs of meeting contingencies have risen at the same time as traditional means of meeting them have weakened. Concurrently, with urban growth there has been a widespread rise in demand for firewood, charcoal, poles and timber. While a rise in the real value of trees and tree products has been common, it has not been universal. Timber prices in India rose in real terms by 5.8 percent annually in the $1970 \mathrm{~s}$ (Bentley. 1984, p. 17) and continued to rise into the 1980s, but eucalyptus poles in northwestern India have dropped in price after a boom, following widespread plantings on private land. Similarly, the patterns in Africa have been mixed (Leach and Mearns, 1988, p. 
136-146). Taken together, these various trends - of weakened traditional supports, and expanding markets and variable but often rising real prices for trees and tree products - raise and sharpen questions about the past use and future potential of trees as savings banks for the rural poor to help them meet contingencies.

\section{The use of trees to meet contingencies}

There is much scattered evidence to show that trees and tree products are used to cope with contingencies. This evidence could be categorized according to type of contingency, the scale of need, whether the need is sudden or of slow onset, or whether it is unforeseen or foreseen. A more useful classification for our purposes is between direct use of trees or tree products, and their sale or mortgage for cash. This distinguishes subsistence and consumption (direct use) from market relations (sale or mortgage). Direct use tends to involve small quantities, while sale or mortgage can involve both small and large quantities. Moreover, it seems likely that with economic and social change, direct use has and will become relatively less significant and sale for cash more so.

\section{Direct use of trees}

Direct use of trees and tree products to meet contingencies takes three forms. The first is where trees provide resources to deal with seasonal shortages. Trees can be sources of recurrent flows of food, fodder, and other useful material. When these flows are counterseasonal, they help households get through the slack or lean months. For human food, examples include mangoes at the beginning of the rains; uvilla (Pourouma cecropiaefolia), a small tree of Brazil, Colombia and Peru that produces fruit over three months of the wet season; ber (Zizyphus spp.) in North India in the late dry season; and the locust bean (Parkia spp.) maturing in the dry season in the West African savannah. For animal nutrition, some tree fodders similarly become available for livestock in the late dry season, for example Faidherbia albida, formerly termed Acacia albida, which drops its pods when other fodder is scarce.

Trees and tree products that help people and livestock to survive the worst periods of the year reduce vulnerability at that time and diminish the dangers of impoverishment through sale of assets to buy food or through loss of livestock.

The second form of direct use is where a contingency entails a one-off need for trees or tree products. Examples are firewood for funeral pyres or feasts, poles and timber for hut and house building, and replacing a lost boat or canoe. In these cases, ownership of or access to suitable trees can meet the need, while lack of ownership or access can mean impoverishment through having to dispose of other assets or take on debts.

The ultimate contingency is death, with costs of a funeral and wood for a funeral pyre. In India it is reported to be common for trees to be reserved for funeral purposes. One old lady agreed to sell her land only when the purchaser gave her permission to harvest, at a later date, three Acacia arabica trees for her funeral pyre (P.K. Aiyasami, personal communication).

\section{Trees as a source of cash}

Serious contingencies requiring cash are of two main types: those where a large sum is required, often suddenly; and those where only a small sum is needed but people are poor or desperate. Trees play a part in both.

A large sum can be needed urgently for medical treatment, a funeral, rebuilding a house or hut or replacing lost or damaged capital equipment (draught oxen or buffalo, a fishing boat or net, etc.). Large sums may be borrowed but the debt often cripples. 
palm trees in the Kilifi District of Kenya. Transactions could be for palms and land together, or for palms on their own. Parkin noted that the greatest and most common contingent expenditure causing poorer people to dispose of their land and palms was marriage and bride-wealth. Others were expenses for a funeral or sacrifice; the costs of having a traditional doctor during the long illness of a family member; and money for food after a poor harvest or other similar contingencies. Of these he found that costs of bride-wealth and funerary expenditures had risen greatly. "Whatever the 'last straw' contingency is," Parkin concluded, "the sale or pledging of palms and land is the surest way to raise cash quickly" (Parkin, 1972, p. 59-60).

The best-documented type of crisis is the need for cash to buy food. This can follow some natural disaster such as drought and floods or may result from a series of other contingencies and needs for money. Caplan's study of a Swahili community on the East African coast was conducted during very dry years when one reason for the sale of trees was "sheer lack of cash; several people sold a few (coconut) trees here and there to make ends meet" (Caplan, 1975, p.42).

In the Panchmahals District of Gujarat in 1987, some small farmers survived the drought by selling eucalyptus trees from their land ( $\mathrm{H}$. Jagawat, personal communication). In 1988, a family of six living off less than 0.25 ha in the Kakamega District of Kenya reported that they usually sold a eucalyptus pole in February or March, a lean season for them, in order "to buy food and soap". For the Mbeere in Kenya, Brokensha and Riley (1980, p. 127) found that for many families, burning and selling charcoal were the only ways of raising money "to meet expenses such as school fees or even for the purchase of food when the rains fail".

\section{IN LATIN AMERICA farmers often plant trees and sell them to raise cash for weddings or other contingencies}

A tragic example of the cutting and sale of trees to buy food has been vividly recounted by Hartmann and Boyce (1983, p. 160-167). In a Bangladesh village, a landless family - Abu, Sharifa and their six children - had suffered a long impoverishing sequence, selling land in a famine; doing badly in land inheritance divided among four brothers, and mortgaging and selling their wooden bed, cow, plough and land bit by bit to meet a succession of needs, including medicine for Abu's sick mother and for Abu himself when he had paratyphoid. Sharifa's earrings and gold nose pin followed. Out of food, in debt, with creditors pressing for repayment at a time of year when cash and food were short, and needing money to buy seed to plant on share-cropped land, Abu cut down first the young mango tree, and then the young jackfruit tree on their small plot to sell the wood and roots for firewood. In the words of the book:

Abu chops off another root, and continues, "There is no rice in my household and I have six children to feed. In June I cut down my mango tree and now I am chopping up my jackfruit tree. My children will never eat fruit - how can I afford to buy it in the Bazaar? Rich people in this country don't understand how my stomach burns.

Yesterday I went to Mahmud Haji's house and asked him to advance some mustard seed. The ground is ready for planting, but I have no cash to buy seed. He told me, 'Buy it yourself. My sharecroppers have to provide their own seed.' He has bags of mustard seed in his house. How can a man be so mean?"

Abu arranges the cut roots into a neat pile. "I'll sell the roots as firewood too, " he says, "Tomorrow I'll carry the wood to town" (Hartmann and Boyce, 1983, p. 167).

The case is cruel. The loss of the trees was a loss not just of appreciating capital, but also of 
future benefits from fruit. But the point is that where there is a local market for firewood, trees on homestead plots are assets that can be cut and sold at short notice to meet urgent needs.

\section{The use of trees as savings}

In many parts of the world, livestock have been the main source of cashable savings for poor people, and have been accumulated as part of a deliberate strategy for survival. With human and animal population pressures on resources, increased privatization of land, diminished access to common grazing and small landholdings, the scope for keeping livestock as savings has diminished. It is perhaps no coincidence that in areas of very dense pressure, and where tenure of trees is secure, there has been a tendency for tree cover to increase. One example is from near Kano in northern Nigeria. A study there (Falola et al., 1984) compared aerial photographs from 1972 with others from 1980 and 1981 to find an 18.5 percent increase in tree density, attributed to natural regeneration following drought and to deliberate tree planting by farmers, 75 percent of whom in a sample said that they planted trees. This was despite earlier alarms that the urban demand for wood would lead to local deforestation. Another example is in the Kakamega District of Kenya, where a meticulous study based on aerial surveys and ground control (Bradley, Chavangi and van Geldar, 1985) found that the density of planted trees varied with population density, and inversely with the average size of holdings. In such conditions, trees may well be substituting for livestock as savings banks, with poor people planting and retaining trees as part of their long-term strategy.

\section{IN GUJARAT, INDIA one farmer raised eucalyptus trees to redeem kind he had pledged for a loan}

Examples of the use of trees as cashable savings are reported from many parts of the world. In Costa Rica and Ecuador it is common for farmers to plant a few trees around their dwellings in their fields' end cut and sell them for timber when money is needed for a wedding or a major cash outlay (Foley and Barnard, 1984, p. 40). In Garhi village in Uttar Pradesh, Vidyarthi (1984, p. 829) found that though most trees belonged to the large landholders, others did own a few trees that were planted in their courtyards or on patches of land that were not suitable for agricultural crops. The wood from such trees was used only on special occasions or in emergencies, such as a marriage feast or burning of the dead. In Kerala, although landholdings are often very small, large numbers of trees are grown. Though the principal species are coconuts and cocoa, farmers often include a few timber trees as well, and slowmaturing species such as teak and mahogany are sometimes grown as long-term investments (Foley and Barnard, 1984, p.40-41). In the Kakamega District of Kenya, exotic trees are planted as crops, or as a form of investment, to pay school fees, etc. (Chavangi, Engelhard and Jones, 1985, p. 11).

Dowry and wedding expenses can be provided for by trees. In Turkey, it is reported (Foley and Barnard, 1984, p. 40) to be traditional to plant trees on the birth of a female child, as a kind of down-payment for her wedding.

The value of trees in strategies for savings and security is enhanced by their use to obtain credit and liquidate debt. Concerning credit, tree pledging or leasing is practiced in Nepal, Nigeria, Sierra Leone and Ghana (Fortmann, 1985, p. 232). In India a case is reported where an enterprising bank manager gave a consumption loan with trees as security (Aloysius Fernandez, personal communication). From her field research in Karnataka, Hill reports that:

"The possibility of letting out small plots for wood planting provides impoverished men with a reliable type of credit, since the lump sum granted them at the outset is automatically liquidated by the landowner's share of the net value of the wood when it is sold, which is usually agreed as one-half" (Hill, 1982, p. 159). 
As regards liquidating debt, only one example is known to us. This is a farmer, Kalji Chatra of Thala village in the Panchmahals District of Gujarat, who pledged a small plot of land to raise Rs3000 to marry his son. Since the pledgee had the right to cultivate, there was no interest payable, which makes this a favourable case for redemption. The farmer planted 200 eucalyptus, and cut and sold them after only three years for Rs5000 with which he redeemed the land and invested in a better pair of bullocks (from an interview in February 1986).

Both the Karnataka practices of leas-ing out small plots of land, and the Panchmahals example of redeeming a debt by growing trees on a small plot, indicate the potential of using tree growing to avoid or escape damaging debt. In the Karnataka practice, not only is credit obtained and indebtedness avoided, but at the end of the lease the lessor receives half of the net value of the wood as a further lump sum; nor is there any interest on the credit to be paid in the interval. In the Panchmahals example, it is noteworthy that the debt did not take long to repay. In good growing conditions, the appreciation in value of trees is like a very high interest rate in a savings bank, suggesting that poor people with suitable small plots of land may be able to accumulate wealth in trees fast enough to pay off debts even when interest rates are high.

\section{Trees as poor people's assets}

As savings and security against contingencies for poor people, trees can be compared with other assets- jewellery, large stock, small stock, land and bank deposits.

\section{Disadvantages}

The most marked comparative disadvantages of trees concern rights, cashability, marketing and risk of loss.

Land rights. Although tree tenure theoretically is separable from land tenure, in practice many obstacles prevent poor people without land from planting or owning trees. Proposals to permit landless and poor people to grow trees on public and wastelands, such as roadsides, canal banks and other common or government land, face bureaucratic and departmental problems. A proposal for tree rights for the landless on such land in Bangladesh was taken over by the Forest Department. In India, however, tree patta programmes, designed to give the poor and landless rights to raise and use trees on such land, have been adopted in several states including Bihar, Uttar Pradesh, West Bengal and Maharashtra. It remains to be seen how well these programmes can overcome the land access problem.

Tree rights and cashability. Rights to jewellery, livestock, land and bank deposits are usually clear (though they can be complicated with large stock), and rights of owners to lease, mortgage, pledge or sell such assets are usually undisputed and unimpeded by law or bureaucratic regulation. But rights and cashability are quite often restricted with trees. The poor are meant to benefit from the trees planted, but often do not own them or have rights to harvest them. Even where trees are on their own land, the poor are often prohibited by law, and impeded by bureaucracy, from cutting them down when they want. Eckholm et al. (1984, p. 56-57) report several examples. In parts of the Sahel farmers are unwilling to grow certain valuable trees because they are on the Forest Department's list of protected species. To harvest trees, farmers have to prove that they planted them and then go through the laborious process of getting a permit to cut. In the Dominican Republic, Honduras, and some other countries, ownership of all trees is vested in the government, and there are penalties for cutting any trees without permissions even those standing on a peasant's own land. There are also laws in the Philippines controlling the cutting of trees and the process of getting a cutting permit is slow and cumbersome; as a result, some small farmers who have invested in tree growing find it difficult to harvest and sell their own trees. 
Marketing. In India, N.C. Saxena (personal communication) has investigated the comparative prices of forest produce obtained by farmers and prevailing in market outlets in 12 locations in six states, and has found the highest return to farmers to be 43 percent (for local mango in Moradabad in Uttar Pradesh) and the lowest to tee only 1 percent (for teak in the Taigad District of Maharashtra), with a total of eight of the 12 cases receiving less than 20 percent. Similarly, in two West African situations, Baah-Dwomoh (1983, in Arnold, 1988, p.16) found producers receiving as a proportion of the final retail price only 11-13 percent for wood cut and stacked at the farm gate, and only 1-1.5 percent for standing wood.

There are several explanations for these low producer prices. First, wood (though not most other tree products) has a high weight to value ratio, and costs of transport are high. Poor people are at a disadvantage. Cash from the sale of the small amounts that can be headloaded will meet only small needs. Poor people often do not have draught animals and carts; to hire these itself requires outlays and indebtedness. The alternative of selling standing trees or wood on site puts the seller at a disadvantage.

In addition, much lower prices are reported for small lots of wood than for large, and big commercial buyers such as pulp factories may not be interested in buying small lots at all.

Risk of loss. Risk of loss of trees as assets is a less clear-cut disadvantage. The vulnerability of trees varies. In the early stages of growth, and especially if they are planted on common land, trees require protection from grazing animals or they will not survive. In dense stands in dry conditions fire is a hazard. Cyclones can blow trees down. Pests may also cause losses. Theft and malicious damage are dangers. In ancient Greece, cutting one's defeated opponents' olive trees was a severe infliction of economic damage. On the outskirts of Pune in India, the three-year-old agroforestry trees of the Centre for Development Studies and Activities were cut down and palms were cut up so that they could not be replanted; this was a reprisal and attempted intimidation because the Centre was tracking and exposing a land racket (Anita and Cristopher Benninger, personal communication, 1986). In other conditions, trees can be very safe, as reported by Pliny in the first century AD:

"The whole wood or forest (of incense trees in the South Arabian coast) is divided into certain portions, and every man knoweth his own part: nay, there is not one of them will offer wrong unto another, and encroach upon his neighbours. They need not set any keepers for to look unto those trees that be cut for no man will rob from his fellow if he might, so just and true they be in Arabia" (Pliny, 1964 edition).

\section{Advantages}

On the other hand, in some respects trees have clear advantages over other types of assets. The most marked of these concern biology and economics:

Cheap establishment and maintenance. Tree seedlings rarely cost much and have a trivial starting cost compared with jewellery, livestock, land, or bank deposits. Often seeds can be gathered and planted, or saplings can be found and transplanted, with little or no cost except labour. Even where seedlings are purchased, they are usually cheap. Costs of watering and protecting young trees vary considerably and can be high, but once established, trees require comparatively little maintenance. In fact, under conditions of scarce capital and labour trees are a rational use of resources for poor farmers, especially those needing to devote a substantial part of their labour to non-farm employment.

\section{the right to harvest "savings trees" is essential}

Rate of appreciation. In tropical conditions where rainfall is adequate, trees usually grow very fast. Leucaena leucocephala is an outstanding example. Small stock, especially goats, can

share the advantage, by breeding fast. In good conditions trees, as also small stock, can have 
a dramatic advantage over bank deposits. A study in Kenya (UNDP/World Bank, 1987) estimated the discounted returns to tree growing and charcoal-making for smallholders and forest workers to be 31 percent. Low rates of interest combined with inflation often mean that savings deposits earn negative interest in real terms, whereas most trees not only maintain or improve their value during inflationary periods, but also appreciate rapidly in value from low starting investment costs.

\section{ADEQUATE TRANSPORT CAPABILITY is essential it poor farmers are to gain [air prices for wood}

Divisibility. If trees are sold for fuel, poles or local building materials, they are divisible into small units to fit needs closely. Part of a tree can be cut, or if trees are small, whole trees are like small units of currency. The advantages of small stock and low value jewellery are similar, but trees are as good or better.

Regeneration. Many trees grow back after pollarding or coppice after cutting. The nearest equivalent to coppicing among other assets is with livestock dependent on limited private supplies of fodder, where the sale of sterile dry females or surplus males improves milk productivity and per unit breeding potential. With other assets, there is no equivalent: jewellery, bank deposits, and land do not coppice when cashed.

\section{Implications for research}

The evidence and analysis presented have implications for research. More empirical studies are needed of the potential and use of trees as savings banks and buffers, especially by poorer people.

Important topics include:

- security of rights and freedom to sell, including relations with various forest administrations;

- marketing arrangements in practice, including cooperative marketing (as with tree growers' cooperatives in Gujarat), smallholder outgrower schemes for pulp factories, arrangements for transport, and prices under different conditions;

- comparative analysis of the costs and benefits to poor people of different types of assets in different conditions, including trees of different types;

- more studies similar to that by Shah (1988) which examine small farmer behaviour where freedom to cut and sell is vested in the farmer, and fully credible; and

- studies of programmes or conditions in which landless people have or acquire disposable rights to trees without necessarily acquiring rights to the land on which the trees grow or stand.

\section{Implications for policy}

Policy implications are linked with a shift in thinking to place more emphasis on enabling poor people to acquire and accumulate assets to meet contingencies. Almost all people who are defined as coming the poverty lines in terms of flows of income and consumption (food, goods in kind and cash) already have strategies for piecing together a living, sometimes with a wide repertoire varying by season and location. A normal professional approach is to try to assure them of employment or an asset that will provide for all or almost all their needs. An 
alternative is to reinforce their existing strategies and back them up, by adding to their assets, security and repertoire. Thus a household that is below some notional livelihood line may be able to move above it through the addition, not of a complete new livelihood, but of a significant component. If this is an appreciating asset to meet contingencies, the benefits can be strong: less anxiety, greater security, and more ability to think and plan ahead, less need for the goodwill of the powerful and rich, and so a weakening of dependent relationships which exploit the poor; less danger of becoming permanently poorer, for example, by having to sell land and become landless, or by running into debt; and the direct benefits of being able to deal better with sickness, accidents, education costs and the like.

Thus trees as assets for the poor promise benefits in health, education and social relations, as well as the more obvious long-term economic benefits.

Many of the policy implications will be specific to places and people, but four can be generalized.

\section{Marketing and prices}

Ease of marketing and good prices are vital for growers yet, in the case of trees, these aspects are complicated by the gestation period of at least several years. Tree marketing cooperatives and special arrangements for bulking up and purchase of small lots are indicated where the purchaser is a pulp mill or other large-scale purchaser. Outgrower schemes for small farmers, comparable to those in East Africa for tea, deserve investigation. Where a new tree product is to be marketed, adequate numbers of trees and levels of production are needed for viability. In new settlements in Sri Lanka, this is sought with improved mangoes through subsidized planting in household clusters (M.P. Moore, personal communication).

Marketing information is alive vital. When it was discovered that in some cases almost half the retail price in nearby markets for the first trees sold in the West Bengal Group Farm Forestry Programme had been retained by intermediaries (Shah, 1988), the Forest Department responded with an effort to improve market information to strengthen the bargaining position of sellers.

\section{Land reform}

Land reform has faced many problems. Some can be mitigated by trees, especially now that they are worth more than in the past. For example, the very small plots issued to landless households in the Kerala reform were valuable for the scope they gave for growing a few trees. Similarly, poor-quality land which is released under ceiling legislation in India has, through trees, a higher potential now than it would have had a decade or two ago. This is illustrated by the West Bengal Group Farm Forestry Programme in the Arabari Range of the Midnapur District, in which eucalyptus were planted on 43 ha of lateritic soil used by 144 poor families. Most of the land had been allocated through land reform but had little potential for crops and was open- to common grazing. Shah (1988) found in his study of 59 of these poor and almost landless families that they spent the lump sums received from the sale of trees as follows: 38 percent on purchase of irrigated land, 21 percent on other productive expenditure, 14 percent on housing, and 22 percent on marriages. Almost all the cash from tree sales was thus used by these poor people to better their economic or social condition in some long-term manner. This demonstrates that even a limited land reform that allocates small plots of lowgrade land to landless households deserves scrutiny for potential gains through lump sums for savings in trees which can be used to secure permanent improvements in livelihood and well being.

\section{Tree reform}

The separability of tree tenure from land tenure (Fortmann and Riddell, 1985; Fortmann and 
Bruce, 1988) opens up scope for rights for the landless to trees on common land or public land including forests. This can be through allocations of trees already growing, or through new planting. Tree reform that allocated trees and rights to plant trees on the fringes of blocks of forest land, for example, could make a major impact on the deprivation of the landless and poor who live nearby.

\section{Ownership, rights and information}

Ownership, rights and information are crucial for the poor. For trees to be good banks and buffers, ownership and rights must be clear and known. If rights to cut and sell are uncertain, or cannot be exercised immediately when needs arise, much of the value of trees to the poor is lost. To restrict cutting and selling trees is like prohibiting people from withdrawing money deposited in a bank, unless perhaps by bribing the bank manager or his staff.

The policy issue here is of immense importance because of the common and deeply held belief among foresters, administrators and other professionals that poor people cannot be, and should not be, trusted with rights to do what they wish with trees. The belief, sincerely held, is that poor people so badly need to fulfill their requirements for daily subsistence that given the rights and the option, they will not care for their trees as a medium- or long-term investment, but cut them down quickly. The policy conclusion is a need, in the interests of the environment. to prohibit the cutting or harvesting of trees without permission.

This view appears mistaken. Conditions differ, and overgeneralizing is a danger. But it is probably widely true that, perversely, legal restrictions on ownership and harvesting create the very conditions they seek to prevent. Poor people who are not sure of their rights to trees will either harvest them quickly or neglect them.

Similarly, restrictions and legal provisions can be disincentives to plant and protect trees. One common fear is that planting trees will lead to loss of land. For example, in an area in Kenya which had been resettled, the new residents feared that if they planted trees, the Kenya Woodfuel Development Programme might later lay claim to their land (Chavangi, Engelhard and Jones, 1985, p. 13).

On the other hand, when rights are clear, known and credible, poor people plant, protect and reserve trees beyond normal bureaucratic and professional expectations. An outstanding example is the agroforestry project launched in Haiti in 1982. In contrast with earlier approaches that restricted rights to cut, the project treated trees as a cash crop for peasants, and from the start made it clear that "You will be the owners of any trees planted", and "As far as we're concerned, you can cut the trees when you want": (Murray, 1984, p. 53). On this basis, the project was outstandingly successful, exceeding its targets many times.

\section{TREE SEEDLINGS have a trivial starting cost compared with other investments}

A social anthropologist who was involved has summarized the experience as follows:

"Peasants originally plant the trees with a view to income generation, but many end up preserving the trees as insurance against emergencies. This meant that, though the tree planting went much faster than we ever creamed possible because of the cash generating focus, the tree harvesting is going slower because of the risk calculus of the peasant owners" (Gerald Murray, personal communication 1986).

Trees have the great advantage over most other crops in that harvesting wood can not only be deferred, but is the equivalent of reinvestment, which leads to higher returns later. When trees are appreciating in value, there is all the more reason to struggle to hang on to them. The extent to which poor people take the long view and the tenacity with which they retain 
trees can be illustrated by examples. A family in the Purulia District of West Bengal

(interviewed in May 1988) described how they coped with the monsoon failure of 1977-78 by first borrowing food and then selling, in this sequence, ornaments, bullocks, goats, hens and ducks, and only then trees-one tamarind and two neem. The long-term view is also reflected in the practice reported in northeastern Thailand; where large trees remain in farmers' fields, "they are preserved 'for the children' even though they may be in the middle of the paddy and require heavy pruning" (Grandstaff et al., 1985).

The ultimate test is what poor people themselves want. The findings of a review of the Madhya Pradesh Social Forestry Project (MPSFP) in India (Madhya, 1984) may be typical. Sessions were held with poor people to ask them their preferences for how wood from social forestry should be distributed. Four options were presented. It was difficult to get participants even to discuss the first three involving the panchayat; organized cutting followed by distribution; and subsidized purchase by the poor. The participants overwhelmingly favoured the option that divided up trees on the plantation equally, with each family allowed to gather wood from designated trees.

Poor people, like those who are not poor, are thus deeply concerned with rights and ownership. For trees to be good banks and buffers, the people must own them and be allowed to harvest, use and sell them at will and for fair prices.

Legally, farmers need full rights to their trees. Beyond that, they must know what their rights are, and they must be enforceable. Unfortunately, confusion and ignorance about the legal position and rights are common, not just among potential or actual tree growers, but also among officials. In one Indian district, the district-level officials did not know which trees were restricted and which were not. The findings of a study in South Wollo in Ethiopia (Bendz and Molin, 1988, p. 2932) are probably typical of conditions elsewhere: different officials gave different answers about rights of ownership and about permissions needed to harvest and market trees.

\section{TWO TEAK "SAVINGS ACCOUNTS" for a poor family}

The final condition concerns official attitudes. The implication of the thrust of this article is that the major obstacle to tree planting lies with officials and other outsiders, with laws and regulations, and with their implementation. Officials are often reluctant to give up power and to trust the poor. They sometimes even pretend that regulations exist when they do not, so that they can maintain control and extract illegal rents. As in so many domains of rural development, it is not just legal change, but the assertion and claiming of rights that are imperative. This requires combinations of organization and pressure from the poor, support from activist NGOs and enlightened administration. As so often in rural development, the perceptions and commitment of officials are a key to change.

\section{Conclusion}

Trees owned and grown by the poor are not a panacea, but the evidence assembled indicates that they have more potential for reducing deprivation than has been and their potential is increasing. Seen from the point of view of the poor themselves, they are like savings bank accounts with low initial deposits and high rates of appreciation. Where ownership and rights to harvest and sell are secure, poor people plant more and harvest less than expected. The question is whether the lessons of Kenya, Haiti, West Bengal and elsewhere will be learned, or whether normal custodial and bureaucratic reflexes will prevail in the name of conservation, with the propagation and enforcement of more draconian rules that will deter the planting, protecting and saving of trees by poor farm families. Liberalizing the rules and assuring security of rights to poor farmers could at a stroke transform conditions and provide incentives to plans and protect trees, to the benefit simultaneously of the poor, the national economy and 
the environment.

\section{Bibliography}

Arnold, J.E.M. 1988. Tree cultivation the household economy and food security. Background paper for the Expert Consultation on Forest and Food Production/Security, Bangalore, India, February 14-20.

Baah-Dwomoh, J. 1983. Estimating stumpage value of wood in the Sahel. Washington, D.C., World Bank. (mimeo)

Bailey, F.G. 1957. Caste and the economic frontier: a village in highland Orissa. Manchester. UK, Manchester Press.

Bendz, M. \& Molin, P.E. 1988. Trees grow in Wollo. Vaxjo, Sweden. Rural Development Consultants AB.

Bentley, W.R. 1984. The uncultivated half of India: problems and possible solutions. Ford Foundation Delhi Discussion Paper Series, No. 12.

Bradley, P.N., Chavangi, N. \& van Geldar, A. 1985. Development research and planning in Kenya. Ambio 14(4-5): 228236.

Brokensha, D. \& Riley, B.W. 1980. Mbeere knowledge of their vegetation and its relevance for development: a case-study from Kenya. In Brokensha, D., Warren, D.M. \& Werner, O., eds. Indigenous knowledge systems and development. p. 113-129. Lanham, MD, University Press of America.

Brokensha, D., Riley, B.W. \& Castro, A.P. 1983. Fuelwood use in rural Kenya: impacts of deforestation. Revised draft report. New York, Institute for Development Anthropology.

Cain, M. 1981. Risk and insurance: perspectives on fertility and agrarian change in India and Bangladesh. Population and Development Rev. Vol. 7, No. 3.

Campbell, J.G. \& Bhattrai, T.N. 1983. People and forests in hill Nepal: preliminary presentation of community forestry household and ward leader survey. (mimeo)

Caplan, A.P. 1975. Choice and constraint in a Swahili community: property hierarchy and cognatic descent on the East African coast. Oxford, UK, Oxford University Press.

Centre for Science and Environment (CSE). 1985. The state of India s environment 198485, the second citizen's report. New Delhi, CSE.

Chambers, R. 1983. Rural development: putting the last first. Harlow, UK, Longman.

Chambers, R. \& Longhurst, R. 1986. Trees, seasons and the poor. In Longhurst, R., ed. Seasonality and poverty p. 44-50. IDS Bulletin, Vol. 17, No. 3.

Chavangi, N.A., Engelhard, R.J. \& Jones, V. 1985. Culture as the basis for implementing self-sustaining woodfuel development programmes. Nairobi, the Beijer Institute.

Douglas, J. et al. 1982. Forest farming: prosperity for India. Debra Dun, India, Natraj Publishers.

Eckholm, E. et al. 1984. Fuelwood. the energy crisis that won't go away. London, Earthscan/International Institute for Environment and Development. 
Falola, J. et al. 1984. Fuelwood in contemporary Kano. Paper presented to the 27th Annual Conference of the Nigerian Geographical Association. Nsukka, Nigeria, Univ. of Nigeria.

Foley, G. \& Barnard, G. 1984. Farm and community forestry. Earthscan Technical Report No. 3., London, International Institute for Environment and Development.

Fortmann, L. 1985. The tree tenure factor in agroforestry with particular reference to Africa. Agroforestry Systems 2: 229-251.

Fortmann, L. \& Riddell, J. 1985. Trees and tenure: an annotated bibliography for agroforesters and others. Madison, WI, Land Tenure Center, Univ. of Wisconsin.

Fortmann, L. \& Bruce, J.W. 1988. Whose trees? Proprietary dimensions of forestry. Boulder, CO, Westview Press.

Grandstaff, S. et al. 1985. Trees in paddy fields in northeast Thailand. In Marten, G.C., ed. Traditional agriculture in Southeast Asia: a human ecology perspective. Boulder, CO, Westview.

Hartmann, B. \& Boyce, J.K. 1983. A quiet violence: view from a Bangladesh village. London, Zed Press.

Hill, P. 1982. Dry grain farming families: Hausaland (Nigeria) and Karnataka (India) compared. Cambridge, UK, Cambridge University Press.

Hirway, I. 1986. Abolition of poverty in India with special referent e to target groups approach in Gujarat p. 140. New Delhi, Vikas Publishing House.

Leach, G. \& Mearns, R. 1988. Bioenergy issues and options for Africa. A report to the Norwegian Ministry of Development Cooperation. London, International Institute of Environment and Development.

Madhya P. 1984. Madhya Pradesh Social Forestry Project (MPSFP) second midterm evaluation. (mimeo)

Mahiti Project. 1983. A question: Why is social forestry not social? Paper prepared for the Ford Foundation Workshop on Social Forestry and Voluntary Agencies, 13-15 April. Badkhal Lake, Haryana, India.

Malhotra, K.C. \& Basak, J. 1984. A note on the cultural ecology of husbanded plants. (mimeo)

Mascarenhas, O.A. (ed.). 1983. Community Forestry Management Progress Report. September 1981-June 1983. Jamshedpur, India, Xavier Labour Relations Institute.

Murray, G.F. 1984. The wood tree as a peasant cash-crop: an anthropological strategy for the domestication of energy. In Foster, C. \& Valdman, A., eds. Haiti - today and tomorrow: an interdisciplinary study. Lanham, MD, University Press of America.

Murray, G.F. 1986. Seeing the forest while planting the trees: an anthropological approach to agroforestry in rural Haiti. In Brinkerhoff. D.W. \& Garcia Zamor, J.C., eds. Politics, projects and people: institutional development in Haiti. New York. Praeger.

Neelakantan, et al. 1982. Social Forestry Project in Tamil Nadu, Survey Report. Tiruchirapalli, India, Department of Economics, Bharathidasan Univ.

Panthaky, F.M. 1982. Farmland plantation including agroforestry. Paper published for the All 
India Social Forestry Workshop. Haryana, India.

Parkin, D.J. 1972. Palms, wine and witnesses: public spirit and private gain in an African farming community. London, Intertext Books.

Pliny, 1964. Natural history. New York, McGraw Hill.

Poulsen, G. 1983. Using farm trees for fuelwood. Unasylva, 35(141): 26-29.

Raintree, J.B. (ed.). 1985. Land, trees and tenure, Proc. International Workshop of Tenure Issues in Agroforestry, 27-31 May. Nairobi, ICRAF.

Sarin, M. et al. 1988. Report of a training programme for environment reconstruction. Chandigarh, India, SAHAJ. (mimeo)

Shah, A. 1984. NREP and IRDP assistance -guidelines to voluntary agencies. In The role of voluntary agencies in wasteland development. Ahmedabad, India, VIKSAT, Nehru Foundation for Development.

Shah, T. 1988. Gains from social forestry lessons from West Bengal. IDS Discussion Paper, No. 243. Brighton, UK, Institute of Development Studies, Univ. of Sussex.

Shiva, V., Sharatchandra, H.C. \& Bandyopadhyay, J. 1981. Social economic and ecological impact of social forestry in Molar. Bangalore, India, Indian Institute of Management. (mimeo)

Slater, G. 1918. Economic studies, Vol. I: Some South Indian villages. Oxford, UK, Oxford University Press.

Srinivas, M.N. 1976. The remembered village. Oxford, UK, Oxford University Press.

UNDP/World Bank. 1987. Kenya: urban woodfuel development program. Washington, D.C., World Bank.

Vidyarthi, V. 1984. Energy and the poor in an Indian village. World Development, 12(8): 821836.

Wiersum, K.F. 1982. Tree gardening and taungya on Java: examples of agroforestry techniques in the humid tropics. Agroforestry Systems, 1: 53-70.

World Bank. 1983a. Gujarat Community Forestry Project Mid-Term Review Mission Report. Washington, D.C., World Bank.

World Bank. 1983b. Uttar Pradesh Social Forestry Project Mid-Term Review Mission Report. Washington, D.C., World Bank.

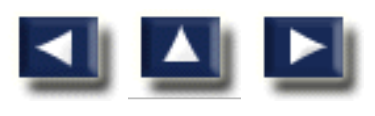

